\title{
REDEFINING THE NATIONAL LEAGUE OF CITIES STATE SOVEREIGNTY DOCTRINE
}

A principal purpose for the creation of our system of constitutional federalism was to vest in a national government the authority to regulate commerce among the states and thereby to avoid the inconsistent pattern of regulation imposed by competing states under the Articles of Confederation." For this reason, the Constitution gives Congress the power to "regulate Commerce . . . among the several states. . .." 2 The federal judiciary has continually monitored the expansion of congressional authority under the commerce clause; it has upheld regulation of even primarily local activities if they have an economic impact in more than one state. $^{3}$

In September 1980, however, in United Transportation Union v. Long Island Rail Road (LIRR), ${ }^{4}$ the Second Circuit announced a decision that could pose a significant threat to congressional power under the commerce clause. The court held the federal Railway Labor Act (RLA) ${ }^{\delta}$ unconstitutional as applied to employees of the state-owned Long Island Rail Road (Railroad). ${ }^{6}$ As a result, employees of the railroad were denied the protection of the right-to-strike

1 In Gibbons v. Ogden, Chief Justice Marshall explained "[ $t]$ he power over commerce ... was one of the primary objects for which the people of America: adopted their government . ..." 22 U.S. (9 Wheat.) 1, 190 (1824). See H.P. Hood \& Sons, Inc. v. DuMond, 336 U.S. 525, 533-34 (1949); Brown v. Maryland, 25 U.S. (12 Wheat.) 419, 446 (1827); Tre Federniss Nos. 6, 7, 11, 22 (A. Hamilton). See also G. Gunther, Cases and Materuats on Constitutionat law 113 (10th ed. 1980); I B. Schwartz, The Powers of Government 178 (1963); 2 J. Story, Conmantaries on the Constitution 2-3 (5th ed. 1891).

2 U.S. ConsT. art. I, $\$ 8$, cl. 3. The commerce clause was designed to suppress the "interfering and unneighbourly regulations of some states [because] ... if not restrained by a national control [these regulations would prove to be] ... . serious: sources of animosity and discord ...." THE FEDERAIIST No. 22 (A. Hamilton).

${ }^{3}$ For examples of the reach of the commerce clause into primarily local activities, see United States v. Sullivan, 332 U.S. 689 (1948) (upholding federal legislation prohibiting druggists from relabeling pills that had been shipped under correct label in interstate commerce); Wickard v. Filburn, 317 U.S. 111, 118 (1942) (upholding federal farm production quota as applied to small dairy farm, extending to "production not intended in any part for commerce but wholly for consumption on the farm.").

4634 F.2d 19 (2d Cir. 1980), cert. granted, 49 U.S.L.W. 3954 (U.S. June 22 , 1981) (No. 80-1925).

545 U.S.C. $\$ \S 151-188$ (1976 \& Supp. III 1979). See note 111 infra.

6634 F.2d at 20. See text accompanying notes 99-103 infra. 
provisions of the $\mathrm{RLA}^{7}$ and were enjoined from striking under the New York State Taylor Law. ${ }^{8}$

The LIRR decision was based on the state sovereignty doctrine articulated by the Supreme Court in 1976 in National League of Cities $v$. Usery $(N L C):^{9}$ Under this doctrine, federal legislation, even if valid as applied to private commercial activity, is unconstitutional insofar as it "directly displace[s] the States' freedom to structure integral operations in areas of traditional governmental functions . ..."10 The Second Circuit's application of the NLC state sovereignty doctrine to the state-owned Railroad relied in part on a reading of $N L C$ advanced by constitutional law scholars Frank Michelman and Laurence Tribe. ${ }^{11}$

In essence, the Michelman-Tribe interpretation 12 of $N L C$ rejects the notion that states have any inherent rights under the Constitution. Instead, the states' right to challenge the constitutionality of federal legislation is derived from the rights of private individuals to receive basic social services. The Second Circuit implemented this theory by characterizing the Railroad's passenger service as a basic social service. ${ }^{13}$ The right-to-strike provisions of the federal RLA were invalidated, therefore, in order to protect the individual rights of the recipients of the railroad service.

The $L I R R$ decision raises the possibility that the NLC state sovereignty doctrine will be used to undermine valid congressional efforts to regulate interstate commerce. The unintended consequence of the Michelman-Tribe theory has been to broaden the potential application of the state sovereignty doctrine, because the integral and traditional governmental functions identified by the Court in $N L C$ may be interpreted now to include any basic social service provided by a state. Especially as interpreted by the Second Circuit

745 U.S.C. $\$ \$ 151-164$ (1976 \& Supp. III 1979). "Although not explicitly set forth in the RLA, the parties may resort to self-help once the RLA's procedures designed to induce agreement have been exhausted." $634 \mathrm{~F} .2 \mathrm{~d}$ at $20 \mathrm{n.2}$ (citation omitted).

8 N.Y. Crv. SERv. LAw $\$ \$ 200-214$ (McKinney 1973 \& Supp. 1980).

9426 U.S. 833 (1976).

$10 \mathrm{Id}$. 852. In NLC, the terms "integral" and "traditional" are used together to describe the state governmental activities that come under the state sovereignty doctrine. Id. 852, 855. See LIRR, 634 F.2d at 25 n.16; Michelman, States' Rights and States" Roles: Permutations of "Sovereignty" in National League of Cities v. Usery, 86 YaTE L.J. 1165, 1172 n.28 (1977).

11634 F.2d at 25 n.15. See Michelman, supra note 10; Tribe, Unraveling National League of Cities: The New Federalism and Affirmative Rights to Essential Governmental Seroices, 90 HaRv. L. REv. 1065 (1977); text accompanying note 103 infra.

12 See note 85 and text accompanying notes 83-91 infra.

13634 F.2d at 26. 
in LIRR, therefore, the state sovereignty doctrine could permit a state to frustrate a whole range of federal legislation simply by assuming ownership of a new service operation.

This Comment is a response to the potentially unbridled state sovereignty doctrine heralded by the $L I R R$ decision. The application of NLC's state sovereignty doctrine must be limited to ensure that states cannot unduly frustrate congressional authority under the commerce power. This Comment, therefore, advances a political process analysis of the state sovereignty doctrine that provides such a limit. The analysis rejects interpretations of NLC that acknowledge constitutional rights in either states or individuals. Instead, the process analysis views the Court's role in $N L C$ as one of policing the political accountability of Congress and of assuring that Congress not be permitted to regulate activities when it is institutionally insensitive to the costs of compliance. The judiciary's role, therefore, is to identify this class of activities and to deny congressional authority to regulate them under the commerce power.

\section{The Modern Commerce Clause and The State SOVEREIGNTY DOCTRINE}

The Supreme Court first suggested the broad scope of congressional power under the commerce clause in the venerable case Gibbons $v$. Ogden, ${ }^{14}$ in which Chief Justice Marshall announced with characteristic expansiveness that Congress's "plenary" power over commerce reaches all "commerce which concerns more states than one." 15 According to Chief Justice Marshall, the commerce power "may be exercised to its utmost extent, and acknowledges no limitations, other than are prescribed in the Constitution." 16 Mostly dicta, ${ }^{17}$ his views of the breadth of the commerce power have never been exceeded. ${ }^{18}$

Despite the Marshall Court's receptivity to broad exercise of the commerce clause, Congress declined to engage in large-scale

1422 U.S. ( 9 Wheat.) 1 (1824).

15 Id. 194.

$16 \mathrm{Id} .196$.

17 The actual holding in Gibbons was quite narrow. A steamboat monopoly, granted by New York State and operating between New York and New Jersey, was invalidated because it conflicted with a federal licensing statute. The constitutionality of the federal statute was upheld under the commerce clause. Id.

18 For other statements by the Marshall Court on the breadth of the commerce clause, see Brown v. Maryland, 25 U.S. (12 Wheat.) 419, 446 (1827) (Marshall, C.J.); McCulloch v. Maryland, 17 U.S. (4 Wheat.) 316, 405-06 (1819) (Marshall, C.J.); Martin v. Hunter's Lessee, 14 U.S. (1 Wheat.) 304, 324-26 (1816) (Story, J.). 
regulatory activity until the late nineteenth century. ${ }^{13}$ By that time, however, the Court had grown less solicitous of congressional power. In cases such as United States v. E.C. Knight Co., ${ }^{20}$ for example, the Court demonstrated its restrictive approach to congressional regulation of private commercial activity. ${ }^{21}$ Even into the early 1930s, the same narrow reading of the commerce clause frustrated major pieces of President Roosevelt's. New Deal legislation. ${ }^{22}$ The Court's view at that time was that the tenth amendment's reservation of powers to the states placed a limit on the reach of Congress's commerce power. ${ }^{23}$

Finally, however, acceding perhaps to the sentiment exemplified by President Roosevelt's court-packing plan, ${ }^{24}$ the Court rejected a tenth amendment challenge to the National Labor Relations Act of $1935^{25}$ in NLRB v. Jones \& Laughlin Steel Corp. ${ }^{26}$

19 The first large-scale regulatory acts were the Interstate Commerce Act of 1887, ch. 104, 24 Stat. 379 (current version at 49 U.S.C. $\$ 1-27$ (1976 \& Supp. III 1979)), and the Sherman Anti-Trust Act of 1890, ch. 647, 26 Stat. 209 (current version at 15 U.S.C. $\$ \$ 1-7$ (1976)). These early national regulatory schemes represented congressional responses to the needs of a new, national economy made possible by the development of transportation, industrialization, and communication. See generally G. GuNTHen, supra note 1, at 133.

20156 U.S. 1 ( 1895 ).

21 In Knight, the Court struck down the government's attempt, under the Sherman Act, to break up a corporate acquisition that gave a single manufacturer control of over 98\% of America's sugar refineries. In its analysis of the commerce power's breadth, the Court drew a distinction between direct and indirect effects on commerce; it held that because manufacturing affected commerce only indirectly, the commerce power did not authorize congressional regulation of manufacturing. See also Hammer v. Dagenhart, 247 U.S. 251 (1918) (striking down statute prohibiting interstate commerce in the products of child labor); Adair v. United States, 208 U.S. 161 (1908) (striking down a federal "yellow dog" contract restriction).

22 E.g., Carter v. Carter Coal Co., 298 U.S. 238 (1936) (Bituminous Coal Conservation Act); Schechter Poultry Corp. v. United States, 295 U.S. 495 (1935) (National Industrial Recovery Act).

23 Writing for the Court in Schechter Poultry, Chief Justice Hughes expressed the fear of an overbroad interpretation of the commerce clause:

If the commerce clause were construed to reach all enterprises and transactions which could be said to have an indirect effect upon interstate commerce, the federal authority would embrace practically all the activities of the people and the authority of the State over its domestic concerns would exist only by sufferance of the federal government.

295 U.S. at 546.

24 See genetally R. Jackson, The Struggle for Judictal Supremacy: A Study of a Crusis IN AMErucan Power Polrincs 176-96 (I941); Stem, The Commerce Clause and the National Economy, 1933-1946, 59 Hanv. L. Rev. 645, 645-93 (pt. 1), 883-947 (pt. 2) (1946).

25 National Labor Relations Act, ch. 372, 49 Stat. 449 (1935) (current version at 29 U.S.C. $\$ \$ 151-166$ (1976 \& Supp. III 1979)).

26301 U.S. 1 (1937). The Court held that Congress could regulate labor relations at any manufacturing plant selling its products across state lines because a work stoppage at any such plant "would have a most serious effect upon interstate commerce." Id. 41 . 
Following Jones \& Laughlin, which signalled the Court's return to a more expansive reading of the commerce clause, the Court consistently rejected tenth amendment attacks on congressional regulation of private commercial activity. ${ }^{27}$ United States $v$. Darby, ${ }^{28}$ decided in 1941, upheld minimum-wage, maximum-hour regulations regarding the production of goods for interstate commerce ${ }^{29}$ and ended (at least for the time being) ${ }^{30}$ the tenth amendment's use as an independent limitation on the commerce power. A unanimous Court, speaking through Justice Stone, declared that "[t]he [tenth] amendment states but a truism that all is retained which has not been surrendered." ${ }^{31}$ Since Darby, congressional action under the commerce clause as applied to private commercial activity has been free of tenth amendment encumbrances. All Congress need show is that it has a "rational basis for finding a chosen regulatory scheme necessary to the protection of commerce," 32 and the legislation falls within the scope of the commerce power. ${ }^{33}$

The law regarding congressional regulation of state and local governmental activities, however, has not followed the same path. The Court initially refused to distinguish, for the purpose of determining the validity of commerce clause legislation, between state governmental activity and private commercial activity. Accordingly, in the first major case testing the constitutionality of congressional regulation of a state activity, a unanimous Court in United States v. California ${ }^{34}$ upheld the application of federal safety regulations

27 E.g., United States v. Sullivan, 332 U.S. 689 (1948); United States v. Darby, 312 U.S. 100 (1941); United States v. Rock Royal Co-op, 307 U.S. 533 (1939); Currin v. Wallace, 308 U.S. 1 (1939).

28312 U.S. 100 (1941).

29 Fair Labor Standards Act of 1938, ch. 676, 52 Stat. 1060 (current version at 29 U.S.C. $\$ \$ 201-219$ (1976 \& Supp. III 1979)). The original version of the Fair Labor Standards Act (FLSA) covered only employees of private industry. Congress extended the FLSA's coverage to all state employees in 1974, thus precipitating National League of Cities v. Usery, 426 U.S. 833 (1976). See Fair Labor Standards Act Amendments of 1974, Pub. L. No. 93-259, $\S 6,88$ Stat. 58 (codified at 29 U.S.C. $\$ 203(\mathrm{e})(1976))$.

30 That is, until the decision in National League of Cities. See notes 54-71 infra \& accompanying text.

31312 U.S. at 124.

32 Katzenbach v. McClung, 379 U.S. 294, 304 (1964). Accord, Fullilove v. Klutzmick, 448 U.S. 448 (1980); Heart of Atlanta Motel, Inc. v. United States, 379 U.S. 241, 258, 262 (1964). See generally L. Trube, Amerucan Constrtutional. LAW $\$ 5-5$ (1978).

33 Katzenbach, 379 U.S. at 304 . Of course, the commerce power is constrained by other, non-tenth amendment, constitutional limitations. E.g., United States v. Jackson, 390 U.S. 570 (1968) (sixth amendment); Mabee v. White Plains Publishing Co., 327 U.S. 178 (1946) (first amendment).

34297 U.S. 175 (1936). Accord, Parden v. Terminal Ry., 377 U.S. 184 (1964); California v. Taylor, 353 U.S. 553 (1957). 
to a state-owned freight railroad." The Court declared that a "state can no more deny [Congress's power to regulate commerce] than can an individual." ${ }^{36}$ Consistent with Darby, the Court recognized no affirmative limitations on federal power in the reservation of state powers by the tenth amendment: "The sovereign power of the states is necessarily diminished to the extent of the grants of power to the federal government ...." 87

Although subsequent cases, ${ }^{38}$ relying on California, also approved Congress's use of the commerce power to regulate state governmental activity, the Court in the late 1960s indicated a renewed interest in principles of state sovereignty. In Maryland $v$. Wirtz,"39 the Court declared that the courts have "ample power to prevent ... 'the utter destruction of the state as a sovereign political entity' " 40 even as it upheld the application of the federal minimumwage law to employees of state-owned schools and hospitals." Justice Douglas's dissent, however, argued for greater solicitude for state sovereignty interests. ${ }^{22} \mathrm{He}$ characterized the regulation of state governmental activity, unlike the similar regulation of private commercial activity, as an "invasion of state sovereignty protected by the Tenth Amendment that is in my view not consistent with our constitutional federalism." 43

35297 U.S. at 186.

36297 U.S. at 185. The language of the tenth amendment ostensibly speaks to states and individuals as equals: "The powers not delegated to the United States by the Constitution, nor prohibited by it to the States, are reserved to the States respectively, or to the people." U.S. CoNSr. amend. X.

37297 U.S. at 184. This position seemingly foreclosed the states from erecting a barrier against congressional action.

38 Parden v. Terminal Ry., 377 U.S. 184 (1964); California v. Taylor, 353 U.S. 553 (1957).

39392 U.S. 183 (1868), overruled, National League of Cities v. Usery, 426 U.S. 833,855 (1976). 198.

40 Id. 196. The majority in Wirtz, however, held California controlling. Id.

The Supreme Court has long asserted that the Constitution guarantees the continued existence of the states as sovereign political units. See, e.g., Metcalf \& Eddy v. Mitchell, 269 U.S. 514, 523 (1926) ("neither government may destroy the other nor curtail in any substantial manner the exercise of its powers"); Texas v. White, 74 U.S. (7 Wall.) 700, 725 (1869) ("[t]he Constitution, in all provisions, looks to an indestructible Union, composed of indestructible States"); Lane County v. Oregon, 74 U.S. (7 Wall.) 7I, 76 (1868) ("in many articles of the Constitution the necessary existence of the States, and, within their proper spheres, the independent authority of the States, is distinctly recognized").

41392 U.S. at 193-99.

42392 U.S. at 201-05. Wirtz was a 6-2 decision. Justice Stewart joined Justice Douglas's dissent.

43392 U.S. at 201. 
Justice Douglas's concern that the federal government could use the commerce clause to "devour the essentials of state sovereignty" 44 was echoed by the Court in Fry $v$. United States. ${ }^{45}$ Upholding under the commerce clause the constitutionality of temporary federal wage controls on state employees, ${ }^{46}$ the Court nevertheless stated that " $[\mathrm{t}]$ he [tenth] Amendment expressly declares the constitutional policy that Congress may not exercise power in a fashion that impairs the States' integrity or their ability to function effectively in a federal system." 47 Fry thus increased the likelihood that the tenth amendment might be used as an affirmative limitation on Congrèss's commerce power as applied to state governmental activity.

Justice Rehnquist, in dissent, added support to the tenth amendment protection suggested by the majority, ${ }^{48}$ providing the first articulation of the modern state sovereignty doctrine. In Justice Rehnquist's opinion, a state, unlike an individual, can assert an "affirmative constitutional right, inherent in its capacity as a State, to be free from . . congressionally asserted authority." 49 According to Justice Rehniquist, both the tenth and eleventh amendments demonstrate that Congress is "not free to deal with a State as if it were just another individual or business enterprise subject to regulation." 50

44 Id. 205.

46421 U.S. 542 ( 1975 ).

${ }^{46}$ Id. 548. Cf. Edelman v. Jordan, 415 U.S. 651 (1974) (eleventh amendment barred district court order requiring state to pay retroactive benefits to aged, blind, and disabled plaintiffs); Younger v. Harris, 401 U.S. 37, 43-54 (1971) (comity, equity, and federalism precluded federal injunction against state criminal prosecution); Oregon v. Mitchell, 400 U.S. 112, 124-26 (1970) (held unconstitutional congressional legislation lowering the voting age to eighteen in all state elections; the federal action usurped a uniquely state function that the Constitution impliedly reserved to the states) (opinion of Justice Black announcing the judgment of the Court).

For a more comprehensive examination of the Supreme Court's heightened sensitivity to state sovereignty interests in the 1970s, see generally Note, Municipal Bankruptcy, The Tenth Amendment and the New Federalism, 89 HARv. L. REv. 1871, 1873-76 (1976); Note, The Constitutionality of Federal Regulation of Municipal Securities Issuers: Applying the Test of National League of Cities v. Usery, 51 N.Y.U. L. REV. 982, 998-1000 (1976).

47421 U.S. at 547 n.7. "While the Tenth Amendment has been characterized as a 'truism' . . it is not without significance." Id.

48 Id. 549.

$49 \mathrm{Id}$. 553. Justice Rehnquist found the source of this state power "solely [in] ... a concept of constitutional federalism." Id. 554 .

50 Id. 557. Justice Rehnquist cited Hans v. Louisiana, 134 U.S. 1 (1890), to support the proposition that the Constitution's framers conferred upon the states attributes of sovereignty apart from the specific provisions of the tenth and eleventh amendments. 
Having placed state sovereignty on tenth amendment grounds, Justice Rehnquist acknowledged that it nevertheless would be necessary to draw a line between state functions protected by state sovereignty and those activities properly subject to congressional regulation.51 By way of example, he reasoned that the state-owned railroad in California was not "sufficiently closely allied with traditional state functions" 52 to deserve constitutional protection. On the other hand, the state-owned schools and hospitals in Wirtz qualified as protected state functions. ${ }^{.33}$

In 1976, a plurality of four, with the separate concurrence of Justice Blackmun, adopted the reasoning of Justice Rehnquist's Fry dissent in NLC.54 Expressly overruling Wirtz, 55 the Court held unconstitutional the 1974 legislation extending federal minimumwage and maximum-hour provisions to nearly all state employees. ${ }^{56}$ The offending legislation was declared unconstitutional to the extent that it "displace[d] the States' abilities to structure employeremployee relationships" 57 in areas of "integral" 58 and "traditional" ${ }^{89}$ state and local governmental functions. ${ }^{60}$

$61 \mathrm{Id} .558 \mathrm{n} .2$.

ธ2 Id. 558.

63 Id. Although he agreed with the result reached in California, Justice Rehnquist declared that the statement in that case that a "state can no more deny . . . [Congress's plenary power to regulate commerce] than can an individual," was "demonstrably wrong." Id. 552.

54426 U.S. 833 (1976). Although it overruled Wirtz, the NLC Court affirmed Fry. The basis for the distinction is not immediately clear, but the Court acknowledged that the federal wage freeze challenged in Fry was temporary and did not increase the burden on the state's treasury. Id. 853. See text accompanying notes $144-47$ infra.

85426 U.S. at 855.

66 Fair Labor Standards Act Amendments of 1974, Pub. L. No. 93-259, §6, 88 Stat. 58 (codified at 29 U.S.C. $\$ 203$ (e) (1976)). The FLSA amendments challenged in NLC were additions to the same act held constitutional in Darby. See notes 28-31 supra \& accompanying text. The original FLSA, as enacted in 1938, specifically excluded the states and their political subdivisions from its coverage. Fair Labor Standards Act, ch. 676, §3(d), 52 Stat. 1060 (1938).

The NLC Court, finding that state sovereignty operated as an affirmative constitutional prohibition, rendered its holding consistent with Darby, in which the Court stated: "Whatever their motive and purpose, regulations of commerce which do not infringe some constitutional prohibition are within the plenary power conferred on Congress by the Commerce Clause." 312 U.S. at 115 (emphasis added).

57426 U.S. at 851 . See id. 847.

58 Id. 851, 852, 854 n.18, 855.

$58 \mathrm{Id} .851,852,855$.

60 Although the language of the tenth amendment directly addresses only the "States" and the "people," the Court in NLC applied the state sovereignty doctrine to local "political subdivisions" of states because they "derive their authority and power from their respective States." Id. 855-56 n.20. 
The Court first recognized that the legislation was unquestionably within Congress's commerce power and valid as applied to private commercial activity. As applied to "States qua States," ${ }^{11}$ however, the legislation encountered the "constitutional barrier" 62 of state sovereignty. Justice Rehnquist, writing the plurality opinion, stated:

We have repeatedly recognized that there are attributes of sovereignty attaching to every state government which may not be impaired by Congress, not because Congress may lack an affirmative grant of legislative authority to reach the matter, but because the Constitution prohibits it from exercising the authority in that matter. ${ }^{63}$

The case, therefore, was remanded for the district court to determine which of the affected state governmental activities fell within the protected area of integral and traditional governmental functions and therefore were outside Congress's power to regulate under the commerce clause. ${ }^{64}$ Thus, for the first time since the 1930s, the Court held unconstitutional a congressional exercise of the commerce power. ${ }^{\text {65 }}$

Justice Blackmun, casting the "pivotal" 68 fifth vote, submitted a separate concurrence joining the Court's opinion with the understanding that the Court was adopting a balancing approach. According to Justice Blackmun, when the federal interest in commercial regulation is "demonstrably greater" than the impact on the state function, state compliance with the federal law would be "essential." 87

In a strong dissent, Justice Brennan, joined by Justices White and Marshall, attacked the plurality opinion as "an abstraction without substance." 68 Justice Brennan denied that a state sovereignty doctrine placing states on different grounds from individuals

61 Id. 847.

62 Id. 841. The Court reserved opinion whether the state sovereignty doctrine applied to other sections of the Constitution, such as the spending power. Id. 852 n.17.

B3 Id. 845 .

64 Id. 856. For the NLC decision after remand, see National League of Cities v. Marshall, 429 F. Supp. 703, 705-07 (D.D.C. 1977).

65 The most recent Supreme Court case to invalidate federal legislation enacted under the commerce power had been Carter v. Carter Coal Co., 298 U.S. 238 (1938). See notes 19-23 supra \& accompanying text.

${ }^{66}$ See LIRR, 634 F.2d at 24 (quoting State Dep't of Transp. v. United States, 430 F. Supp. 823,825 (N.D. Ga. 1976)).

67 NLC, 426 U.S. at 856 (Blackmun, J., concurring).

68426 U.S. at 860 (Brennan, J., dissenting). 
existed anywhere in the Constitution. ${ }^{60}$ He criticized the Court for repudiating the "principles governing judicial interpretation of our Constitution settled since the time of Mr. Chief Justice John Marshall, [by] discarding his postulate that the Constitution contemplates that restraints upon exercise by Congress of its plenary commerce power lie in the political process and not in the judicial process." "70

Justice Stevens, in a separate dissent, indicated that he could not adopt the majority's reasoning without appropriate restraints on its application. He stated: "Since I am unable to identify a limitation on [the commerce power] that would not also invalidate federal regulations of state activities that I consider unquestionably permissible, I am persuaded that this statute is valid." 71

\section{Post NLG: The Ambiguity and Improvidence of the State Sovereignty Doctrine}

A distinct danger inheres in the ambiguous definition of the state sovereignty doctrine provided by the Supreme Court in NLC. Without restraints, this doctrine can be used by particular interests to frustrate otherwise valid federal regulatory schemes to the detriment of the intended beneficiaries of the federal regulation. The NLC state sovereignty doctrine presents this problem because, to date, judges and scholars have not succeeded in identifying precisely the doctrine's constitutional basis or its ultimate political rationale.

A close examination of the NLC opinion, recent scholarship, and relevant principles of democratic political theory will be undertaken in an effort to identify more precisely the constitutional foundations of the state sovereignty doctrine. The objective is to construct an understanding of the doctrine that will both explain and limit its application, thereby precluding frustration of Congress's constitutional authority to regulate interstate commerce.

Most notably absent from the NLC opinion is a standard permitting identification of those "integral" and "traditional" state governmental activities that should be protected from federal intrusion. In his dissent in Fry $v$. United States, ${ }^{72}$ Justice Rehnquist acknowledged that some doctrinal line would have to be drawn and

69 Id.

70 Id. 857.

71 Id. 881 (Stevens, J., dissenting).

72421 U.S. 542, 549 (1975) (Rehnquist, J., dissenting). 
suggested some tests that might prove useful; ${ }^{73}$ the Court in NLC, however, adopted no test or rationale. Instead, it provided a short list of state and local governmental activities that deserve state sovereignty protection. ${ }^{74}$ Although it admitted that this list is "not . . . exhaustive," 75 the Court afforded little guidance in identifying other activities that might deserve protection.

Justice Blackmun's concurring opinion in NLC ${ }^{76}$ compounds the ambiguity of the state sovereignty doctrine. ${ }^{77}$ Justice Blackmun conditioned his crucial fifth vote on his understanding that the Court's opinion involved a balancing approach, ensuring that the judiciary would not invalidate federal legislation in which the federal interest is "demonstrably greater" and state compliance with federal standards would be "essential." 78 Because the Court's opinion implicitly rejected a balancing approach, ${ }^{79}$ the authority of such an approach remains unclear. Some lower federal courts have adopted balancing tests; ${ }^{80}$ others have failed to weigh federal interests. ${ }^{81}$

73 Id. 558 \& n.2. Justice Rehnquist suggested, without deciding the question, that 'the traditional distinction between 'governmental' and 'proprietary' activities might in some form prove useful in such line drawing. The distinction suggested in New York v. United States, 326 U.S. 572 (1946), between activities traditionally undertaken by the State and other activities, might also be of service . . . Id. 558 n.2. The Court did not discuss either of these tests in NLC.

74 For example, "fire prevention, police protection, sanitation, public health, and parks and recreation." 426 U.S. at 851 .

75 Id. 851 n. 16.

78 Id. 856.

77 See, e.g., Tennessee v. Louisville \& Nashville R.R. Co., 478 F. Supp. 199, 206 (M.D. Tenn. 1979) ("[s]ince Justice Blackmun's concurrence was the swing vote in the ultimate holding [in $N L C$ ], it is impossible to discern what test, if any, was established for analyzing congressional exercises of power pursuant to the Commerce Clause").

78426 U.S. at 856.

79 The Court did not discuss the nature or the importance of the federal interests involved. Moreover, the Court declared: "We do not believe particularized assessments of [the] actual impact [of the amendments] are crucial . . ." 426 U.S. at 851. Instead, the Court based its holding on the finding that application of the amendments would "significantly alter or displace the States' abilities to structure employer-employee relationships" in areas of integral and traditional governmental functions. Id. See generally Matsumoto, National League of Cities-From Footnote to Holding-State Immunity from Commerce Clause Regulation, 1977 ARIz. ST. L.J. 35, 71 n.193; Tushnet, Constitutional and Statutory Analyses in the Law of Federal Jurisdiction, 25 U.C.L.A. L. REv. 1301, 1338, 1340 (1978).

so See, e.g., United Transp. Union v. Long Island R.R. Co., 634 F.2d 19 (2d Cir. 1980), cert. granted, 49 U.S.L.W. 3954 (U.S. June 22, 1981) (No. 80-1925); Peel v. Florida Dep't of Transp., 600 F.2d 1070 (5th Cir. 1979); Friends of the Earth v. Carey, 552 F.2d 25 (2d Cir. 1977); Usery v. Bd. of Education, 421 F. Supp. 718 (D. Utah 1976).

81 See, e.g., Amersbach v. City of Cleveland, 598 F.2d 1033 (6th Cir. 1979); United States v. Best, 573 F.2d 1095 (9th Cir. 1978); Virginia Surface Mining and 
Although it eschewed an explicit test, the Court did provide useful guidance by reaffirming its decision in United States $v$. California, ${ }^{82}$ which held that a state-owned railroad is not an activity embraced by the state sovereignty doctrine. ${ }^{83}$ The Court in NLC distinguished public railroad service from police departments because railroad services are "not in an area that the States have regarded as integral parts of their governmental activities." \$4 This distinction, however, does not explain adequately the intended reach of NLC's state sovereignty doctrine. The "integral" and "traditional" language itself does not provide a principled basis for distinguishing between police departments and railroads. Absent a standard for making this distinction, how is a court to determine whether a given state-owned activity is more like a police department or a railroad?

Two leading constitutional law scholars, Frank Michelman ${ }^{85}$ and Laurence Tribe, ${ }^{86}$ have addressed precisely this shortcoming in the NLC opinion; taken together, ${ }^{87}$ they have advanced a novel interpretation of $N L C$ that, admittedly, "leads in directions the Justices do not seem to have intended or anticipated." 88 The Michelman-Tribe theory identifies "individual rights against the government for certain basic services" 89 as the only supportable constitutional foundation for $N L C$ 's state sovereignty doctrine. The essence of their interpretation is that " states as states' under the Constitution are imbued with affirmative duties towards their citizens," 90 and that "the Constitution . . . protects citizens against ill-conceived congressional interference with the states' performance

Reclaimation Ass'n Inc. v. Andrus, 483 F. Supp. 425 (W.D. Va. 1980); Tennessee v. Louisville \& Nashville R.R. Co., 478 F. Supp. 199 (M.D. Tenn. 1979).

82297 U.S. 175 (1936). See text accompanying notes 34-36 supra.

83426 U.S. at 854 n.18.

84 Id. 854 n. $18,854-55$.

85 Michelman, supra note 10.

86 L. Trube, supra note $32, \S 5-22$; Tribe, supra note 11.

87 The works of Michelman and Tribe may be treated together and will be referred to as the Michelman-Tribe theory. As Michelman acknowledged in his opening footnote: "[o]ur two efforts are to a considerable extent overlapping in content and perception .... [and] took shape in our respective minds simultaneously ... at Harvard Law School . . . . Neither of us is surprised at the family likeness in the finished pieces." Michelman, supra note 10, at 1165 n. ${ }^{*}$. See Tribe, supra note 11, at 1066 n.8, 1089.

88 Michelman, supra note 10, at 1166 . Tribe acknowledged: "I haven't a clue what [the Justices really intended], but I doubt that the conclusion of this Article was it." Tribe, supra note 11, at 1066.

80 L. Trube, supra note 32 , $\$-22$, at 315 . See Michelman, supra note 10 , at 1172; Tribe, supra note 11, at 1075, 1076.

90 Michelman, supra note 10, at 1194. 
of that role ..." 91 Michelman and Tribe claim that NLC could not have been based on "any inherent rights of states"; ${ }^{22}$ instead, "the state's right against the federal government in such a case is derivative of the rights of its residents against government." 93

In constructing this interpretation of the state sovereignty doctrine, Michelman and Tribe attempted to enlist the logic latent in the $N L C$ opinion, while remaining faithful to its premises, in an effort to create a "just constitutional order." ${ }^{94}$ Their doctrine "recognizes under the fifth and fourteenth amendments constitutional rights [for individuals] to decent levels of affirmative governmental protection in meeting the basic human needs of physical survival and security, health and housing, employment and educacation." 95 Although the minimum level of government service cannot be determined arbitrarily by the courts, once the state has decided to provide such a service at a given level, the federal government may not regulate it and thereby compel a reduction in the level of service provided. ${ }^{96}$

Michelman and Tribe, however, did not answer adequately the more pressing issue raised by $N L C$ : how to limit its application. Although recognizing that "the opinion's broad rhetoric poses the danger that the decision will be read uncritically as a general vindication of the autonomy of states and municipalities," 97 the affirmative rights analysis, by looking into the future for "a just constitutional system," fails to address NLC's more immediate threat to our constitutional structure. The assertion of a state government's duty to provide essential public services has been used to enlarge, rather than to limit, the protected areas of integral and traditional state functions.

The Second Circuit's decision in LIRR 98 illustrates the degree to which states can rely on the broad rhetoric of the $N L C$ opinion, assisted by the Michelman-Tribe interpretation, to frustrate congressional exercise of the commerce power. In $L I R R$, the court cited Michelman's and Tribe's works in support of its finding that

91 Id. 1186.

92 Tribe, supra note 11 , at 1090 .

93 Id.

94 Id. 1066.

95 Id. See Michelman, The Supreme Court, 1968 Tern-Foreword: On Protecting the Poor Through the Fourteenth Amendment, 83 HARv. L. REv. 7 (1969); Tribe, supra note 11, at 1096.

96 Michelman, supra note 10, at 1190-91; Tribe, supra note 11, at 1090.

97 Tribe, supra note 11 , at 1089. See L. TriBE, stpra note $32, \$ 5-22$, at 300-10. 08 634 F.2d 19 (2d Cir. 1980). 
the state-owned railroad was an "integral governmental function" 00 deserving of the state sovereignty protection announced in NLC. In addition to its local passenger service, the Railroad engaged in more than $\$ 12.1$ million of interstate business annually. ${ }^{100}$ For purposes of the state sovereignty analysis, however, the court characterized it as a "passenger rail service." 101 The court found this service to be within the area of state governmental functions protected by NLC and therefore distinguishable from the state-owned freight railroad denied state sovereignty protection by the Supreme Court in United States $v$. California. ${ }^{102}$ The court, quoting Michelman, specifically based its holding on the reasoning that "the term 'sovereignty' as used in [NLC] has been defined to mean 'the state's role of providing for the interests of its citizens in receiving important social services." " 103

The procedural strategy successfully adopted by New York State in LIRR will be of interest to all state governments. While $L I R R$ was pending in the district court, New York State converted the Railroad, which 'historically has considered itself a 'carrier' within the meaning of the RLA," 104 into a public benefit corporation, thus making the employees "at least facially subject to [New York's] Taylor Law" forbidding strikes by public employees. ${ }^{105}$ Only one

90 Id. 24-25 \& n.15.

$100 \mathrm{Id} .20,23$.

101 Id. 26. The court found that the Railroad is a passenger rail service because only a relatively small portion of its total revenues, which were estimated at more than $\$ 300$ million annually, could be attributed to its freight service. Id. 21 . The Railroad's annual, interstate freight revenue of $\$ 12$ million, however, considered alone, would establish it as a Class II carrier according to the ICC. See ICC General Instructions on Classification of Carriers, 49 C.F.R. Part 1201, 1-1(a) (1980). Hundreds of Class III railroads (those with interstate revenues under $\$ 10$ million) are subject to the RLA. See Brief on Behalf of United Transportation Union, Plaintiff-Appellee and on Behalf of Amicus Curiae at 12, United Transp. Union v. Long Island R.R., 634 F.2d 19 (2d Cir. 1980), cert. granted, 49 U.S.L.W. 3954 (U.S. June 22, 1981) (No. 80-1925).

102634 F.2d at 26 . See text accompanying notes 82-84 supra. The Court in NLC also found its holding to be consistent with the result in California. 426 U.S. at 854 n.18.

103634 F.2d at 25 n.15 (quoting Michelman, supra note 10, at 1172).

104634 F.2d at 23. Section 1 of the RLA provides in pertinent part that the "term 'carrier' includes any ... carrier by railroad subject to the Interstate Commerce Act [ICA] . .." 45 U.S.C. $\$ 151$ (1976). The ICA covers "common carriers" involved in "[ $t]$ he transportation of passengers or property . . . by railroad .... [f]rom one State . . to any other State ...." 49 U.S.C. $\$ 1(1)(1976)$. Indeed, the Railroad has consistently filed reports required by the ICA; its employees receive the benefits of the Railroad Retirement Act, the Railroad Unemployment Insurance Act, and the Federal Employees Liability Act. 634 F.2d at 23 .

Recently, in a decision dealing with another subsidiary of the Metropolitan Transportation Authority, the Interstate Commerce Commission noted that the Railroad is a carrier subject to the RLA. See 634 F.2d at 23 n.12.

105634 F.2d at 21. 
day after reincorporating the Railroad, the state withdrew from its position that the Taylor Law ${ }^{106}$ was inapplicable because of federal preemption; shortly thereafter, it filed an action under the Taylor Law. ${ }^{107}$ The applicability of the RLA then was challenged effectively under the NLC state sovereignty doctrine.

By expanding the scope of its governmental activities, New York State was able to deny railroad employees the protection of the RLA's right-to-strike provisions. ${ }^{108}$ As a result, the state successfully used its Taylor Law ${ }^{109}$ to enjoin any threat of a strike. The Railroad has been declared "a necessary physical link with other railroads in the movement of a heavy volume of interstate freight...."110 Nonetheless, because the NLC state sovereignty doctrine lacks effective limits, railroad employees were denied a federally created right to strike-a right that has been held essential to the federal labor scheme. ${ }^{111}$

As $N L C$ 's integral and traditional test becomes associated with the provision of any service by a state, the state sovereignty doctrine poses a tremendous threat to our federal system. Other states probably will be quick to adopt the strategy successfully employed by New York State in LIRR: by assuming full ownership of an activity,

106 N.Y. Crv. SERv. LAw $\$ \S 200-214$ (McKinney 1973 \& Supp. 1980).

107634 F.2d at 21 \& n.4.

108 The right to strike is not set forth explicitly in the RLA. The Supreme Court, however, has ruled that the right to resort to self-help is implicit in the statutory scheme. Brotherhood of R.R. Trainmen v. Jacksonville Terminal Co., 394 U.S. 369, 378 (1969).

109 N.Y. Crv. SERv. LAw $\$ \$ 200-214$ (McKinney 1973 \& Supp. 1980). Section 210 (1) provides: "No public employee or employee organization shall engage in a strike, and no public employee or employee organization shall cause, instigate, encourage, or condone a strike."

110 Long Island R.R. Co. v. Brotherhood of R.R. Trainmen, 185 F. Supp. 356, 357 (E.D.N.Y. 1960).

111 Brotherhood of R.R. Trainmen v. Jacksonville Terminal Co., 394 U.S. 369, 378-82 (1969). The Supreme Court made clear that the right to strike was at the heart of the federal labor scheme.

[T] he exercise of plenary state authority to curtail or entirely prohibit self-help would frustrate effective implementation of the Act's process. The disputants' positions in the course of negotiation and mediation, and their willingness to submit to binding arbitration or abide by the recommendations of a presidential commission, would be seriously affected by the knowledge that after these proceedings were exhausted a State would, say, prohibit the employees from striking or prevent the railroad from taking measures necessary to continue operating in the face of a strike.

....

Whether the source of this right be found in a particular provision of the Railway Labor Act or in the scheme as a whole, it is integral to the Act. State courts may not enjoin a peaceful strike by covered railway employees, no matter how economically harmful the consequences may be.

Id. 380-85 (citations omitted). 
a state can avoid a whole range of burdensome federal regulations. ${ }^{112}$ This fear is not unfounded. The likelihood that states would expand their range of governmental activities was presaged by Justice Douglas in a 1946 dissent. The court relied on this dissent in LIRR: ${ }^{113}$

A State may deem it as essential to its economy that it own and operate a railroad, a mill, or an irrigation system as it does to own and operate bridges, street lights, or a sewage disposal plant. What might have been viewed in an earlier day as an improvident or even dangerous extension of state activities may today be deemed indispensable. . . . [A]ny activity in which a State engages within the limits of its police power is a legitimate governmental activity. ${ }^{114}$

The NLC test should be clarified; as Justice Brennan noted in his $N L C$ dissent, the Court's integral and traditional state governmental function "standard is a meaningless limitation on the Court's state-sovereinty doctrine ...." I15 The absence of any meaningful limitation on the application of the doctrine poses a real threat that states, simply by expanding the scope of their governmental activities, may be able to frustrate significantly congressional efforts to design a consistent pattern of national regulation. This broad reading of $N L C$ is possible because the opinion itself fails to articulate adequately its constitutional foundation and thus its implicit limitations.

\section{A Political Process Analysis of the State SOVEREIGNTY DOGTrine}

Basing its decision in part on the Michelman-Tribe interpretation of $N L C,{ }^{116}$ the court in $L I R R^{117}$ focused on the importance of

112 In his NLC dissent, Justice Brennan warned of just this possibility:

Can the States engage in businesses competing with the private sector and then come to the courts arguing that withdrawing the employees of those businesses from the private sector evades the power of the Federal Government to regulate commerce? ... No Principle given meaningful content by my Brethren today precludes the States from doing just that.

426 U.S. at 872-73. Justice Brennan cited Justice Frankfurter's opinion announcing the judgment of the Court in New York v. United States, 326 U.S. 572, 582 (1946). 113634 F.2d at 26.

114 New York v. United States, 326 U.S. 572, 591 (1946) (Douglas, J., dissenting).

115426 U.S. at 871 (Brennan, J., dissenting).

116 See note 11 and text accompanying notes $11-13$ supra.

117 United Transp. Union v. Long Island R.R., 634 F.2d 19 (2d Cir. 1980), cert. granted, 49 U.S.L.W. 3854 (U.S. June 22, 1981) (No. 80-1925). 
the service provided to the Railroad's riders in determining that the RLA's right-to-strike provisions could not be applied. That analysis ignores, however, a more fundamental problem: the state's protection of one group-railroad passengers-correspondingly denies the RLA's protection to another group-railway laborers. ${ }^{118}$ This inevitable conflict results because the right-to-strike provisions, by increasing the cost of rail service, also reduce the availability of the rail service to passengers. ${ }^{119}$ The $L I R R$ analysis simply accorded greater weight to the provision of the service than to the interests of the railway workers as expressed by the RLA. In so doing, the Second Circuit usurped an essentially legislative function, for it is the legislature's prerogative to favor one set of interests over a competing set. As the political process analysis demonstrates, the legislature's prerogative may only be defeated when its process is inherently suspect.

The Supreme Court has never elevated to constitutional status the right to a minimum level of basic social services; ${ }^{120}$ it has never recognized a constitutional right to a minimum wage. Instead, to the extent that such rights exist, they arise by legislative fiat. In any given legislative forum, the conflicting interests are reconciled through the process of compromise. With respect to social services provided by the states, there is a heightened potential for rights in conflict because the compromise struck at the state level may be, and often is, different from that struck in Congress. ${ }^{121}$ This is a wholly predictable consequence of our federal system. The Constitution, therefore, evincing an awareness of this potential for

118 Michelman and Tribe also ignored this condition because they simply sanctified one set of individual rights, those of the recipients of the services, at the expense of the other, those of the laborers.

119 The process analysis, as articulated, presumes this simple function of increased costs and decreased service. It is, of course, possible that a state could respond to an increase in costs by increasing taxes proportionately and thereby avoiding any decrease in service. This latter relationship does not change the operation of the process analysis, because an increase in taxes will generate the same voter dissatisfaction as a corresponding decrease in services. "Increased costs" and "forced relinquishment of important governmental activities" were a principal concerm of the Court in NLC. 426 U.S. at 846-47. See also Michelman, supra note 10, at 1174 .

120 The Court has specifically denied all claims for "fundamental" treatment of basic social services under its equal protection analysis. See, e.g., San Antonio Independent School Dist. v. Rodriguez, 411 U.S. I (1973) (education); Lindsey v. Normet, 405 U.S. 56 (1972) (housing); Dandridge v. Williams, 397 U.S. 471 (1970) (welfare assistance).

Rights the Court has identified as fundamental include interstate travel, Shapiro v. Thompson, 394 U.S. 618 (1969), and privacy in marriage and procreation, Skinner v. Oklahoma, 316 U.S. 535 (1942).

121 Cf. Sanitary Dist. of Chicago v. United States, 266 U.S. 405, 425-26 (1925) (when the federal government "is asserting its sovereign power to regulate commerce ... the interests of the nation are more important than those of any state"). 
conflict, tries to minimize tension by defining the respective powers of the state and federal governments. ${ }^{122}$

Conflicts do arise nonetheless. But when each government is acting within its defined powers, a conflict between them "is not a controversy between equals." 123 The supremacy clause unquestionably favors legislation emanating from Congress. ${ }^{124}$ Only if Congress is acting outside its affirmative grants of power, ${ }^{125}$ or if it encounters an affirmative constitutional limitation, ${ }^{126}$ may the judiciary invalidate a legislative policy. Underlying state policies therefore will prevail. The only checks on the expansion of federal power that exist are the limits imposed by the Constitution. Included within these are principles designed to assure the political accountability of Congress. ${ }^{127}$

In this context, the Court in NLC attempted to define an area of state activity constitutionally sheltered from federal power. The notion of "integral" and "traditional" state functions, however, is not self-defining; it does not, for example, explain how a stateowned commuter railway differs constitutionally from a state-owned freight railroad. Implicit in the Court's analysis is the concern that Congress may be institutionally insensitive to the impact of its legislation on certain state governmental activities. Because of the interposition of state governments between Congress and the electorate, the normal process of political accountability breaks down in cases in which the states have assumed substantial responsibility over a certain function.

The states have certain governmental responsibilities that, without the protection of the state sovereignty doctrine, could be seriously frustrated by federal regulation. Accordingly, when federal regulation prevents the states from providing the kind or level of services expected by their citizens, the state governments, not Congress, are held responsible. In such cases, Congress is no longer

122 The Constitution "conferred certain powers on the state governments, and certain powers on the national government." McCulloch v. Maryland, 17 U.S. (4 Wheat.) 316,327 (1819).

123266 U.S. at 425.

124 U.S. CoNsT. art. VI, $\$ 2$.

125 See L. TruBe, supra note $32, \$ 5-2$.

126 See id. 227.

127 See NLG, 426 U.S. at 875-76 (Brennan, J., dissenting); Wickard v. Filburn, 317 U.S. 111, 120 (1942) ("effective restraints on [Congress's exercise of the commerce power] ... must proceed from political rather than from judicial processes"); Gibbons v. Ogden, 22 U.S. ( 8 Wheat.) 1, 197 (1824). See generally THE FeDERAuIST No. 45 (J. Madison); Wechsler, The Political Safeguards of Federalism: The Role of the States in the Composition and Selection of the National Government, 54 Colom. L. REv. 543 (1954). 
accountable for the negative political consequences of its actions; the process generating the legislation, therefore, is inherently suspect. Such a failure in the normal operation of the political process justifies the invalidation of federal legislation on state sovereignty grounds.

Concededly, the Supreme Court has never spoken in these terms. But the Court's concern for the "essential role of the States in our federal system of government" 128 displays a recognition of the need to preserve the states' own legislative functions. Being "a coordinate element in the system established ... for governing our Federal Union," ${ }^{129}$ the states are entitled to a special deference not given private entities. ${ }^{130}$ Moreover, that the Court was unwilling to disturb the way the states had "structure[d]" their service delivery ${ }^{131}$ implies that in some areas, because the state legislature, not Congress, is the politically responsible governmental entity, it should be free from intrusive federal legislation.

Given the premise that legislative legitimacy flows from political accountability, ${ }^{132}$ it follows from the Court's reasoning that the states may be immune from federal legislation when the state government, and not Congress, is politically accountable. The presumption of validity and supremacy usually accorded federal statutes dissipates when Congress can avoid responsibility for its decisions. In this context, the NLC state sovereignty doctrine

128426 U.S. at 844 . The recognition of a state sovereignty limitation on Congress's exercise of its otherwise plenary powers is not an entirely new constitutional principle. Implicit in the tenth amendment's declaration of the relationship between state and federal powers is the principal that the federal government may not, even when exercising one of its affirmative grants of power, threaten the "separate and independent existence" " of the states. Id. 845. For this proposition, the NLC Court cited Lane County v. Oregon, 74 U.S. (7 Wall.) 71,76 (1868). In Lane County, the Court acknowledged that "in many articles of the Constiution the necessary existence of the States, and, within their proper spheres, the independent authority of the States, is distinctly recognized." Id. 76. Accord, Metcalf \& Eddy v. MitchelI, 269 U.S. 514, 523 (1926); Texas v. White, 74 U.S. (7 Wall.) 700, 725 (1868). The Court in NLC relied on this line of cases as historical, constitutional support for its state sovereignty doctrine. 426 U.S. at 844-45. Contra, Bethlehem Steel Co. v. New York State Labor Relations Bd., 330 U.S. 767, 780 (1947) (opinion of Frankfurter, J.) (Congress "can if it chooses, entirely displace the States to the full extent of the far-reaching Commerce Clause").

129426 U.S. at 849.

By identifying the state sovereignty limitation as implicit in the tenth amendment and the general federalist structure created by the Constitution, the Court in NLC rendered its decision consistent with even the broad reading of the commerce clause offered by Chief Justice Marshall in Gibbons: "[the commerce] power . . . acknowledges no limitations, other than are prescribed in the Constitution." 22 U.S. ( 9 Wheat.) at 196.

130426 U.S. at 845.

131 See id. 847.

132 See text following note 127 supra. 
provides a device the courts can use to allocate decisionmaking authority for certain kinds of decisions to the appropriate body. In so doing, the courts ensure that the "correct" substantive decisions are made.

Moreover, the courts are accustomed to this role. Due process ${ }^{133}$ and voting rights cases, ${ }^{134}$ among others, ${ }^{135}$ all attest to the political policing function undertaken by the courts. Indeed, the Supreme Court has acknowledged this crucial judicial function. In United States v. Carolene Products, ${ }^{136}$ Justice Stone's famous footnote four suggested that "legislation which restricts those political processes which can ordinarily be expected to bring about repeal of undesirable legislation is to be subjected to more exacting judicial scrutiny ...."137 Although Justice Stone was referring to the fourteenth amendment, not the tenth amendment, the point is still clear: the courts are to oversee the smooth running of the democratic political machine. ${ }^{138}$

The NLC Court seems to have been operating under the same imperative. Its solicitude for the "considered policy choices of the States' elected officials" 139 belies an underlying rationale aimed at responsible legislative decisions. Otherwise, there would be no reason to favor the "considered policy choices" of the states over those of the federal government. The Court must have been placing authority in the hands of those who ultimately would be held politically responsible for the policies in question. The Court's formulation of the areas for which the states are ultimately accountable was the "integral and traditional" test; the services found clearly to fall under that rubric were police protection, fire prevention, hospitals, schools, and parks-all areas for which the states

133 E.g., Roe v. Wade, 410 U.S. 113 (1973); In te Winship, 397 U.S. 358 (1970); Griswold v. Connecticut, 381 U.S. 479 (1965). (1962).

134 E.g., Reynolds v. Sims, 377 U.S. 533 (1964); Baker v. Carr, 369 U.S. 186

135 E.g., Graham v. Richardson, 403 U.S. 365 (1971); Brown v. Board of Educ., :347 U.S. 483 (1954).

136304 U.S. 144 (1938).

137 Id. 152 n.4. See also J. Elx, Democracx and Distrust 73-79 (1980).

138 Numerous constitutional theorists have asserted that the judiciary is re: sponsible for policing the processes of representation guaranteed by the Constitution. Ely, for example, argues for "a form of [judicial] review that concerns itself with "how decisions effecting value choices and distributing the resultant costs and benefits are made." ELY, supra note 137, at $75 \mathrm{n} .^{\circ}$. See generally L. LuSKY, BY WHAT RuGHr? (1975); Ball, Judicial Protection of Powerless Minorities, 59 IowA L. REv. 1059 (1974); Rostow, The Democratic Character of Judicial Review, 66 Harv. L. REv. 193 (1952).

130426 U.S. at 848. 
are identified as having primary responsibility. ${ }^{140}$ Public dissatisfaction resulting from the reduced quality or quantity of a service would be directed not at Congress but at the state and local governments considered responsible. Were Congress to create the conditions forcing a curtailment or diminution of such a service, the federal government would be insulated from the political fallout. This is precisely the problem the Court seems to have wanted to avoid in NLC.

The integrity of the states as independent political units depends upon their being free to implement the policies for which they are primarily responsible. The states, unlike private enterprise, cannot shirk their goverernmental responsibilities merely because the costs become too high. As a practical matter, the states will provide some level of police protection regardless of the cost. Severe cost increases are more likely to force the states to abandon other, less crucial, social services. Respect for the independent role of state governments in the federal system dictates that the state legislatures retain control over decisions affecting their ability to provide services for which they are considered responsible. ${ }^{141}$

This political process analysis casts new light on $L I R R$. The Second Circuit's emphasis on the "importance" and the "essential" nature of the service, ${ }^{142}$ although initially attractive, was misplaced. The crucial question is not whether the particular service is "essential," but rather whether Congress, in enacting the challenged legislation, was sufficiently accountable to those affected by its action. If Congress is accountable, then it can be relied upon to weigh the conflicting interests involved and the legislation must be upheld. In $L I R R$, such legislative balancing would have considered the interests of the railway workers and the competing interests of the recipients of the railway service. The right-to-strike provisions of the RLA, therefore, reflect the considered policy choice of Congress to favor the rail workers. Where a showing can be made, however, that Congress is not accountable for its choices, the courts must invalidate the federal legislation, and the states' considered policies will prevail.

140 Id. 851.

141 By the same token, however, some decisions are best left to the federal government. Because of its national constituency and wider perspecive, Congress is presumably more sensitive to the costs, benefits, and variety of interests involved in certain kinds of legislation. Clearly, Congress is best suited to deal with issues of national defense; few would argue that this is an area in which the states should exercise direct control. 
Under this standard, LIRR was wrongly decided, because the court failed to focus on Congress's sensitivity to the costs states would incur in complying with the requirements of the RLA. The RLA indisputably increased the costs of operating an admittedly important and essential service. Because the legislation affected the private railroad industry as well as public carriers, ${ }^{143}$ however, Congress could not have been unaware of or unaccountable for those consequences. Congress, therefore, will be held responsible for fare increases and service curtailments due to the burdens of the legislation. Such political accountability validates the legislative compromise Congress reached in the RLA.

This structural analysis also helps to reconcile the decision in NLC to uphold Fry $v$. United States ${ }^{144}$ but to overturn Maryland v. Wirtz.145 The Court in NLC emphasized that the federal legislation challenged in Fry-the Economic Stabilization Act-"displaced no state choices as to how governmental operations should be structured." 140 Instead, the wage freeze "reduce[d] the pressures on state budgets rather than increase[d] them." ${ }^{147}$ Thus, unlike Wirtz and $N L C$, in which the minimum wage regulations might have forced a diminution in the level of state services, the legislation in Fry did not compel a reduction in state services or a reordering of spending priorities. Fry therefore did not present a situation in which Congress was insulated from the negative political .consequences resulting from a forced diminution in the provision of a state service. The legislation challenged in Fry, therefore, was appropriately upheld.

A recent case, difficult to analyze under the $N L C$ standard, illustrates the application of the political process test. ${ }^{148}$ In Amersbach $v$. City of Cleveland, ${ }^{149}$ the Sixth Circuit held that firefighters ${ }^{150}$ employed at a municipal airport were part of an "integral government function" and therefore not subject to the Fair Labor Standards Act. ${ }^{151}$ The Second Circuit in LIRR, citing Amersbach

14345 U.S.C. $\$ 151$ (1976). See note 104 supra.

144421 U.S. 542 (1975).

145392 U.S, 183 (1968), overruled, National League of Cities v. Usery, 426 U.S. 833,855 (1976).

146426 U.S. at 853 .

$147 \mathrm{Id}$.

148 See generally Note, National League of Cities Crashes on Takeoff: Balancing Under the Commerce Clause, 68 Geo. L.J. 827 (1980).

149598 F.2d 1033 (6th Cir. 1979). The court in Amersbach faulted the NLC opinion for not having "articulate[d] a specific test to be applied ...." Id. 1037. 160 Id. 1034 \& n.l.

161 Id. 1034. 
as support, ${ }^{152}$ excluded the railroad's employees from the federal RLA under the same "integral governmental function" analysis. ${ }^{153}$ Under the political process test, however, the line defining peculiarly state functions falls between these two cases: Amersbach was decided correctly; LIRR was not.

The distinction rests on a finding that the political objections resulting from a railroad strike will be voiced adequately by the substantial private railroad sector in this nation. ${ }^{154}$ The electorate does not necessarily look primarily to the States to provide railroad service; ${ }^{155}$ the increased costs and interruption in service resulting from the federal regulation implicate simply, according to the Court in NLC, "the 'shifting economic arrangements' in the private sector of the economy." 158 Under this test, the Long Island Rail Road is indistinguishable from the state-owned railroad in United States $v$. California, ${ }^{157}$ to which the Supreme Court, in a decision approved in $N L C$, denied state sovereignty rights because this state service "was not in an area that the States have regarded as integral parts of their governmental activities." 158

152634 F.2d at 27.

153 Id.

154 Courts should consider several elements in making such distinctions: the degree to which the service is commonly provided by states or the private sector, historical practice, and the involvement of the federal government. Admittedly, this test closely resembles the integral and traditional test suggested by $N L C$; determinations in the gray areas, therefore, may remain difficult. By supplying a reasoned rationale for this question of fact, however, the process analysis will generate a more consistent and more limited application of the state sovereignty doctrine.

155 See LIRR, 634 F.2d at 27 (noting that "[a]lthough this is a relatively new development, there now is no reasoned basis for finding that the operation of an intrastate passenger service . . . is any less a governmental function than are sanitation or public parks and recreation").

Peculiar or changed circumstances may enable a court to make a justified finding to the contrary. The critical question is whether Congress or the state legislature will be faulted for an insufficient level or quality of service. This flexibility, although much less than that under the ambiguous NLC doctrine, removes the static element from the "traditional" component in the NLC test and thereby assures "one of the happy incidents of the federal system that a single courageous State may ... try novel social and economic experiments without risk to the rest of the country." New York State Ice Co. v. Liebmann, 285 U.S. 262, 311 (1932) (Brandeis, J., dissenting. See also F. Frankfurter, The Public and its Government 49-51 (1930). 156426 U.S. at 849 (quoting Kovacs v. Cooper, 336 U.S. 77, 95 (1949) (Frankfurter, J., concurring)).

157297 U.S. 175 (1936).

158426 U.S. at 854 n.18. See text accompanying notes $82-84$ supra. Perhaps circumstances already have changed to an extent sufficient to sustain, under the process analysis, the Second Circuit's holding in LIRR on the grounds that: (1) New York citizens presently look predominantly to the state to provide this railroad service and (2) the costs to a passenger-commuter line serving a congested corridor in the nation's largest metropolitan area are so peculiar that the private sector's objections will not adequately reflect the costs that riders and citizens will incur if a strike interrupts the service provided by the Railroad. See 634 F.2d at 29-30. 
Unlike state-owned railroads, the service provided in Amersbach is not adequately represented in the private sector, for, as the court found, "[p]rivately-owned airports serving municipalities are virtually unknown." 159 Those who benefit from municipal airports normally will look to their local legislators with demands or complaints. Congress, therefore, is likely to be insensitive to municipal airports' failures to respond to fires.

The political process interpretation of the $N L C$ state sovereignty doctrine will reconcile most of the dissonant concerns expressed in the three opinions filed in NLC. The plurality will be accommodated because the "essential governmental functions" deserving regulatory autonomy will be protected from federal intrusion. The concerns of Justice Blackmun, who was "not untroubled by certain possible implications of the Court's opinion," 180 will be resolved, because the new test will involve an implicit balancing component that will limit the ability of the state sovereignty doctrine to frustrate "demonstrably greater" federal interests. ${ }^{161}$ Most importantly, the process interpretation will provide meaning to the Court's NLC opinion that the dissenters characterized as "an abstraction without substance." 162 In so doing, it will curtail the doctrine's potential to frustrate congressional exercise of the commerce power, thereby mitigating many of the fears expressed by the dissenters. ${ }^{163}$

\section{Conclusion}

The Second Circuit's broad yet plausible reading of the $N L C$ state sovereignty doctrine in LIRR and the threat this reading poses to Congress's power to regulate interstate commerce should leave one, as the $N L C$ opinion left Justice Brennan, "incredulous." ${ }^{164}$ An understanding of this doctrine and its inherent constraints, however, can assuage such fears. As congressional power expanded to reach a greater variety of activities, it encountered new affirmative limita-

159598 F.2d at $1038 \&$ n.7.

160426 U.S. at 856 (Blackmun, J., concurring).

101 Id. It is asserted that a demonstrably greater federal interest will heighten federal legislative accountability.

162426 U.S. at 860 (Brennan, J., joined by White, J., and Marshall, J., dissenting).

103 Justice Blackmun, along with the four dissenters, seemed concerned primarily that an unduly broad reading of the state sovereignty doctrine would frustrate congressional power. Their concerns, therefore, might be satisfied by an understanding of the state sovereignty doctrine that renders it capable of application only within the bounds proposed by the political process analysis.

164426 U.S. at 875 (Brennan, J., dissenting). 
tions-limitations either explicit in the Constitution or implicit in the governmental structure it created. These limitations, however, as exceptions to Congress's otherwise plenary powers, must be de-fined narrowly to reach only those activities requiring protection from federal regulation.

This Comment has advanced a political process analysis that is intended to guide and limit the application of the NLC state sovereignty doctrine. The process analysis directs the courts to invalidate federal regulation of state governmental activities only when Congress is not politically accountable for the costs associated with its legislation. 